\title{
Impact of Improved Water Management Technique for Groundnut in LBP Command Area
}

\author{
J. Bhuvaneswari ${ }^{1}$, G. Thiyagarajan ${ }^{2 *}$, M. Manikandan ${ }^{3}$, \\ S. Thenmozhi ${ }^{4}$ and S. K. Natarajan ${ }^{5}$ \\ ${ }^{1}$ Agricultural College and Research Institute, Tamil Nadu Agricultural University, \\ Killikulam, India \\ ${ }^{2}$ Water Technology Centre, ${ }^{5}$ Department of Agronomy, Tamil Nadu Agricultural University, \\ Coimbatore, India \\ ${ }^{3}$ Agricultural Engineering College and Research Institute, Tamil Nadu Agricultural \\ University, Kumulur, India \\ ${ }^{4}$ Krishi Vigyan Kendra, Tamil Nadu Agricultural University, Pongalur, India \\ *Corresponding author
}

\begin{tabular}{|l|}
\hline Key w or d s \\
$\begin{array}{l}\text { Groundnut, } \\
\text { IW/CPE, Water } \\
\text { saving, Water use } \\
\text { efficiency, Yield }\end{array}$ \\
\hline Article Info \\
\hline $\begin{array}{l}\text { Accepted: } \\
\text { 12 December } 2020 \\
\text { Available Online: } \\
\text { 10 January } 2021\end{array}$ \\
\hline
\end{tabular}

The experiment consisted of improved water management technology (0.6 IW/CPE ratio with gypsum application in splits) and conventional method (Irrigation once in 8-10 days) was conducted in Lower Bhavani Project (LBP) area. The mean total water use under improved irrigation was $486 \mathrm{~mm}$ which was considerably lesser than conventional method which utilized $639 \mathrm{~mm}$ water and quantity of water saving by 31.87 per cent. Averaging over locations, improved irrigation registered a mean yield of $1854 \mathrm{~kg} \mathrm{ha}^{-1}$ which was significantly higher than surface irrigation and normal fertilizer application $\left(1584 \mathrm{~kg} \mathrm{ha}^{-1}\right)$. The average yield increment by improved irrigation was 17.05 per cent over conventional method of irrigation. Higher net income and Benefit Cost ratio of Rs 57,371 ha ${ }^{-1}$ and 2.64 were registered by improved irrigation as compared to Rs 39,916 ha ${ }^{-1}$ and 2.03 respectively under conventionally irrigated and fertilized groundnut. Thus it is evident that adoption of improved irrigation gained an additional mean net income of Rs. 17,455 ha ${ }^{-1}$ than conventional method.

\section{Introduction}

Groundnut (Arachis hypogaea L.), popularly known as "King" of oilseeds. In India, it is grown on an area of $5.53 \mathrm{~m}$ ha, having annual production of $7.4 \mathrm{~m} \mathrm{t}$ with an average productivity of $1338 \mathrm{~kg} \mathrm{ha}^{-1}$ (Anonymous, 2016; Thiyagarajan et al., 2010b). Although
India ranks first in area under cultivation of this crop, the productivity is low compared to other groundnut growing countries. The reason behind that the most of the area is under rainfed and remain as an unpredictable legume, showing inconsistency in pod and oil yields. Further, it has been proved that water is most critical input that effects on crop 
growth and yield, their unavailability leads to great reduction in productivity of groundnut (Ramachandrappa and Kulkarni, 1992; Thiyagarajan et al., 2010c).

In groundnut, the WUE is often expressed as the ratio of pod yield to the amount of water depleted by the crop. In general, the WUE will decrease with increasing number of irrigations in groundnut (Desai et al., 1984; Thiyagarajan et al., 2010a). Similar trend were observed by Narasimham et al., 1977; Reddy and Reddy, 1977. Water use efficiency explains effective utilization of water by crop in terms of water saving as well as yield augmentation.

The field experiments were conducted at Agricultural Research Station, Bhavanisagar under AICRP- Irrigation Water Management project resulted better performance of improved irrigation methods compared to conventional method of irrigation in groundnut. To test verify that proven technology of improved irrigation in groundnut, Operational Research project were conducted at farmers holdings in the kugalur distributory of LBP canal area.

\section{Materials and Methods}

On farm experiment under Operational Research Projecton improved water management technologies in groundnut were conducted in farmers fields one each at head, middle and tail reaches of kugalur distributory of Lower Bhavani Project canal command areas during 2015 and 2016under All India Co-ordinated Project on Irrigation Water Management. The experiment consisted of improved water management technology (0.6 IW/CPE ratio with gypsum application in splits) and conventional method (irrigation once in 8-10 days). The major soil type of the study area was sandy loam in nature and the soil fertility status was low in available nitrogen $\left(198 \mathrm{~kg} \mathrm{ha}^{-1}\right)$, medium in phosphorus $\left(14 \mathrm{~kg} \mathrm{ha}^{-1}\right)$ and high in potash $\left(282 \mathrm{~kg} \mathrm{ha}^{-1}\right)$. Two irrigation methods of groundnut cultivation viz., improved irrigation method and conventional method were compared by using the variety $\mathrm{CO} 2$. The planting of groundnut in the study area was mainly (December - January). The recommended dose of fertilizer 25: 50: $75 \mathrm{~kg}$ NPK ha-1 applied in the form of urea, super phosphate and MOP. The nitrogen and potash in three splits viz., $50 \% \mathrm{~N} \& \mathrm{~K}$ as basal $+25 \% \mathrm{~N}$ and $\mathrm{K}$ at $20 \mathrm{DAS}+25 \% \mathrm{~N}$ and $\mathrm{K}$ at $45 \mathrm{DAS}$ were applied. Gypsum @ $400 \mathrm{kgha}^{-1}$ was applied in splits of $200 \mathrm{kgha}^{-1}$ each at sowing and at $40-45^{\text {th }}$ DAS. The total water use was calculated by adding irrigation water applied and effective rainfall. The details of test verification in the study area are furnished in Table 1. Groundnut yield was recorded and total water used, water use efficiency (WUE) and economics were worked out and presented.

\section{Results and Discussion}

\section{Effect of irrigation on total water used and water use efficiency}

The water use studies of both the methods of irrigation clearly indicated the beneficial effect of improved irrigation in terms of water saving and higher Water Use Efficiency (WUE) (Table 2). The mean total water use under improved irrigation was $486 \mathrm{~mm}$ which was considerably lesser than conventional method which utilized $639 \mathrm{~mm}$ water. Thus a substantial quantity of water saving by 31.87 per cent was noticed due to the adoption of irrigation based on IW/CPE ratio of 0.6 with split application of gypsum application. The higher yield coupled with enormous quantity of water saving under improved irrigation resulted in higher water use efficiency in both the years of experimentation. 
Lenka and Mishra (1973) revealed that highest yield in groundnut was obtained at $25 \%$ depletion of available moisture which was $828 \mathrm{~mm}$ as compared to 50 and $75 \%$ depletion of available moisture with 810 and $730 \mathrm{~mm}$ water, respectively. Hosamani and Janawade (2007) reported that $504 \mathrm{~mm}$ was proved to be sufficient for getting good pod yield in groundnut. Patel et al., 2008 reported that groundnut crop irrigated at $40 \mathrm{~mm}$ cumulative pan evaporation (17 irrigations) registered mean higher value of consumptive use of water $(795.8 \mathrm{~mm})$.

Table.1 Details of ORP on drip fertigation in the kugalur distributory

\begin{tabular}{|l|c|c|}
\hline \multicolumn{1}{|c|}{ Particular } & $\mathbf{2 0 1 5}$ & $\mathbf{2 0 1 6}$ \\
\hline Area of demonstration (ha) & 3.0 & 3.0 \\
\hline No of farmers (Head, middle, tail) & 3 & 3 \\
\hline Name of the farmers & $\begin{array}{c}\text { V.K.Sampath } \\
\text { M.Muthusamy } \\
\text { M.Kuppusamy }\end{array}$ & $\begin{array}{c}\text { M.Muthusamy } \\
\text { K.Chinnusamy } \\
\text { Sathasivam }\end{array}$ \\
\hline Name of the villages & $\begin{array}{c}\text { Vettaikarankoil } \\
\text { Kullampalayam } \\
\text { Bommanaikanpalayam }\end{array}$ & $\begin{array}{c}\text { Kullampalayam } \\
\text { Bommanaikanpalayam } \\
\text { Konnamadai }\end{array}$ \\
\hline $\begin{array}{l}\text { Total rainfall during the cropping } \\
\text { period (mm) }\end{array}$ & 193 & 71 \\
\hline
\end{tabular}

Table.2 Yield, water use, water saving and economics of groundnut

\begin{tabular}{|c|c|c|c|c|c|c|}
\hline \multirow[t]{2}{*}{ Particular } & \multicolumn{2}{|c|}{2015} & \multicolumn{2}{|c|}{2016} & \multicolumn{2}{|c|}{ Mean } \\
\hline & Imp.* & Conv.*** & Imp. & Conv. & Imp & Conv. \\
\hline Yield $\left(\mathrm{Kg} \mathrm{ha}^{-1}\right)$ & 1827 & 1542 & 1881 & 1626 & 1854 & 1584 \\
\hline Percent yield increase & 18.48 & - & 15.68 & - & 17.05 & - \\
\hline Total water use (mm) & 462 & 646 & 510 & 632 & 486 & 639 \\
\hline Percent water saving & 39.83 & - & 23.92 & - & 31.87 & - \\
\hline Water Use Efficiency $\left(\mathrm{kg} \mathrm{hamm}^{-1}\right)$ & 3.95 & 2.39 & 3.69 & 2.58 & 3.82 & 2.49 \\
\hline Cost of cultivation $\left(\right.$ Rs ha $\left.^{-1}\right)$ & 36758 & 42033 & 33890 & 36497 & 35324 & 39265 \\
\hline Gross income $\left(\mathbf{R s ~ h a}^{-1}\right)$ & 91333 & 77083 & 94056 & 81278 & 92695 & 79181 \\
\hline Net income $\left(\right.$ Rs ha $\left.^{-1}\right)$ & 54575 & 35050 & 60166 & 44781 & 57371 & 39916 \\
\hline $\begin{array}{l}\text { Additional net income } \\
\left(\text { Rs ha }^{-1}\right)\end{array}$ & 19525 & - & 15385 & - & 17455 & - \\
\hline B:C ratio & 2.49 & 1.83 & 2.78 & 2.23 & 2.64 & 2.03 \\
\hline
\end{tabular}

*Improved irrigation (Imp.) ** Conventional method (Conv.)

Groundnut pod - Rs.50/kg 
Effect of improved irrigation on groundnut yield

In the present study, yield of groundnut was substantially increased due to the adoption of improved irrigation technology (Table 2). Averaging over locations, improved irrigation registered a mean yield of $1854 \mathrm{~kg} \mathrm{ha}^{-1}$ which was significantly higher than surface irrigation and normal fertilizer application $\left(1584 \mathrm{~kg} \mathrm{ha}^{-1}\right)$. The average yield increment by improved irrigation was 17.05 per cent over conventional method of irrigation. Higher yield under improved irrigation was mainly due to the availability of sufficient nutrient for improving growth and yield attributes. It coupled with adequate availability of soil moisture and nutrients throughout the crop growth period. Climatologically based irrigation scheduling of IW/CPE 0.75 attained higher growth parameters over the other irrigation scheduling as the optimum quantity of water supplied at appropriate interval might have resulted in better root growth without compensating the shoot growth of the crop. While, studies indicate that optimum irrigation frequency supplied to the crop could have retained adequate soil moisture content throughout the growth period of the crop which in turn facilitated better and proper utilization of nutrients thereby increasing yields (Behera et al., 2015; Lokhande et al., 2018).

Irrigation at $0.8 \mathrm{IW} / \mathrm{CPE}$ ratio increased the pod yield by 14.5 per cent and oil yield of groundnut by 16.94 per cent than rainfed check in medium deep alfisols at ICRISAT Centre (Rao et al., 1985). Taha and Gulati (2001) revealed that the pod yield in groundnut increased with increasing IW/ CPE ratio, the maximum yield of 22.4qha-1 was obtained at 1.4 IW/ CPE with $525 \mathrm{~mm}$ evapotranspiration. Raskar and Bhoi (2003) observed that irrigation scheduling at $75 \mathrm{~mm}$
CPE to summer groundnut recorded significantly higher dry pod yield of $34.08 \mathrm{q}$ $\mathrm{ha}^{-1}$. A field experiment was conducted by Bandyopadhyay et al., (2005) on bunchy variety of peanut having IW/ CPE ratio of 0.9 , 0.7 and 0.5 . Result revealed that the total pod yield and water productivity were recorded higher in 0.9 IW/ CPE ratio compared with 0.7 and $0.5 \mathrm{IW} / \mathrm{CPE}$.

\section{Economics of improved irrigation in groundnut}

The economic analysis of both the methods of irrigation (Table.2) revealed that though the cost of cultivation was comparatively higher under improved irrigation it was found to be economically better than conventional method of irrigation. Improved irrigation fetched a mean gross income of Rs.92,695 $\mathrm{ha}^{-1}$ as against Rs 79,181 ha ${ }^{-1}$ under conventional method. In addition, higher net income and benefit cost ratio were also associated with improved irrigation. Higher net income and Benefit Cost ratio of Rs 57,371 ha ${ }^{-1}$ and 2.64 were registered by improved irrigation as compared to Rs.39,916 $\mathrm{ha}^{-1}$ and 2.03 respectively under conventionally irrigated and fertilized groundnut. Thus it is evident that adoption of improved irrigation gained an additional mean net income of Rs 17,455 ha ${ }^{-1}$ than conventional method.

In conclusion the adoption of IW/CPE ratiobased irrigation in groundnut is a relatively cheapest technology that can conserve water and increase profits. The application of irrigation based on IW/CPE ratio in groundnut has convincingly shown that the technique results in high water use efficiency, saves water, provides higher pods yield. However, if not followed properly, it may result in waste of water, time and yield. Application of irrigation based on IW/CPE ratio requires careful study of all the relevant factors like land, soil, water, crop and agro- 
climatic conditions. Adoption of improved irrigation (IW/CPE ratio) with gypsum application in groundnut cultivation is technically feasible and economically viable.

\section{Acknowledgement}

This research work was carried out under All India Coordinated Research Project on Irrigation Water Management, Bhavanisagar centre, Tamil Nadu.

\section{References}

Anonymous, 2016. Area, production and productivity of groundnut in India. http://www.indiastat.com/agriculture/2/a griculturalarealanduse/152/areaundercro p19502015/448934/stats.aspx.

Bandyopadhyay, P.K., Mallick, S. and Rana, S.K. 2005. Water balance and crop coefficients of summer- grown peanut (Arachis hypogaea L.) in a humid tropical region of India. Irrig. Sci., 23:161-169.

Behera, B.S., D. Mohit, A.C. Behera and R.A. Behera, 2015. Weather based irrigation scheduling in summer groundnut in Odisha condition. Intl. J. Agric. Sci. Res., 5: 247-260

Desai, N.D., Joshi, R.S. and Patel, K.R. 1984. Response of summer groundnut to various levels of irrigation on clayey soils. Madras Agric. J., 71: 617-620.

Hosamani, M.H. and Janawade, A.D. 2007. Response of Rabi Groundnut (Arachis hypogaea L.) to Irrigation Schedules and Integrated Nutrient Management in Deep Black Soils of Upper Krishna Command. Karnataka J.Agric. Sci., 20(3): 453-456.

Lenka, D. and Mishra, P.K. 1973. Response of groundnut (Arachis hypogaea L.) to irrigation. Indian J. Agron., 18:492-497.

Lokhande, D.C., N.E. Jayewar and A.G. Mundhe, 2018. Summer Groundnut
(Arachis hypogaea L.) Productivity Influenced By Irrigation Scheduling: A Climatological Approach. Intl. J. Curr. Microbiol. Appl. Sci., 6: 87-91

Narasimham, R.L., Rao, S.I.V. and Rao, S.M. 1977. Effect of moisture stress on response of groundnut to phosphate fertilization. Indian J. Agric. Sci., 47: 573-576.

Patel, G.N., Patel, P.T. and Patel, P.H. 2008. Yield, water use efficiency and moisture extraction pattern of summer groundnut as influenced by irrigation schedules, sulphur levels and sources. SAT e J., 6: 1-4.

Ramachandrappa, B.K. and Kulkarni, K.R. 1992. Pod yield, total water use, consumptive use, and water use efficiency and moisture extraction patterns of summer groundnut as influence by irrigation schedules. $J$. oilseeds Res., 9(1):51-58

Rao, R.C., Singh, S., Sivakumar, M.V.K., Srivastava, K.L. and Williams, J.H. 1985. Effect of water deficit at different growth phases of peanut. I. Yield response. Agron. J., 77:782-786

Raskar, B.S. and Bhoi, P.G. 2003. Response of summer groundnut (Arachis hypogea L.) to irrigation regimes and mulching. Indian J. of Agron., 48(3): 210-213.

Reddy, G.H.S. and Reddy, N.M. 1977. Efficient use of irrigation water for wheat and groundnut. Mysore $J$. Agric.Sci., 11: 22-27.

Taha, M. and J.M.L. Gulati, 2001. Influence of irrigation on yield and moisture utilization of groundnut (Arachis hypogaea L.). Ind. J. Agron., 46: 523-527

Thiyagarajan, G. and M.V. Ranghaswami. 2010a. Modeling yield response of groundnut to deficit irrigation at different growth stages by FAO CROPWAT. Madras Agricultural Journal, 97 (4-6):145-148. 
Thiyagarajan, G., D. Rajakumar, R. Kumaraperumal and M. Manikandan. 2010b. Response of yield and yield attributes of groundnut to moisture stress - A review. Agricultural Reviews, 31 (3), 210-216.

Thiyagarajan, G., M.V. Ranghaswami, D.
Rajakumar and R. Kumaraperumal. 2010c. Irrigation planning in command areas using crop coefficient model. Madras Agricultural Journal, 97 (1-3): 43-45.

\section{How to cite this article:}

Bhuvaneswari, J., G. Thiyagarajan, M. Manikandan, S. Thenmozhi and Natarajan, S. K. 2021. Impact of Improved Water Management Technique for Groundnut in LBP Command Area. Int.J.Curr.Microbiol.App.Sci. 10(01): 1457-1462.

doi: https://doi.org/10.20546/ijcmas.2021.1001.173 